\title{
CHILD REFUGEES IN EUROPE
}

\author{
Seda YAZGAN HADZIBULIC, PhD. C.
}

Northeastern Illinois University, Faculty of Political Science, sedayazgan87@gmail.com

\begin{abstract}
Article history:
Accepted 20 April 2020

Available online 31 August 2020

\section{Keywords:}

Refugees,

Children Refugees,

$E U$,

$U D H R$,

European Union Refugee

Policies.

A b s t r a t

This paper provides an overview of the literature on the current refugee crisis in Europe, which primarily focuses on the situation of refugees that are children. Due to its magnitude, the world is currently facing one of the biggest humanitarian crises it has ever witnessed. Millions of people and young children have fled their home countries and became refugees The horror of wars and conflicts has affected all of the refugees while undoubtedly, it has had a more profound and significant impact on the children refugees. The rights of these refugee children are paramount, and one of these rights is that they are provided with safety and resources that will help them cope with the crisis while also ensuring they are provided a chance to a brighter future.
\end{abstract}

The United Nations Declaration of Human Rights. The European Union and the whole world have a direct responsibility to provide basic necessities such as food, shelter, education, health which can help and alleviate the mental and emotional suffering which the refugee children face. My research will focus on three important aspects of the child refugee's crisis in Europe The general conditions of the children refugees, the conditions of camps especially in Italy, Greece, and Spain, and how the crisis has affected their daily lives and mental health. In the end, my conclusion will focus on the question of, what are the policies which Europe has to change which are designed to help and lead the refugee children which to a better future.

The aim of this paper to have a better understanding of children refugees in Europe and to raise global awareness about their conditions and the humanitarian crisis at hand. Research will consist of information from academic articles, published books, various websites, data from previous studies, and resources.

\section{Introduction}

In 2016, global forced displacement hit record-high numbers - the highest in recorded human history of 63.5 million people. (Edwards 2016). According to the Global Trends released by the UN Refugee Agency (2016), on average, 24 people were forced to flee their homes every minute in 2015 - four times more than it was reported a decade earlier. The numbers are staggering; and among millions of uprooted are hundreds of thousands of unaccompanied children traveling to Europe hoping to find the promise of safety, security and sanctuary. Currently, the vast majority of child refugees coming to Europe are from war-torn countries. Overall, the number of asylum applications from these countries began to rise, especially after 2012 when, in lieu of the Syrian war, and the ongoing conflicts in Somalia and Iraq, the
Taliban resurfaced in Afghanistan. (Mortimer 2016, as cited in Chak, 2017). There are more refugees coming out of Syria than any other nation (Amnesty International Ltd. 2014, as cited in Sirin, Rogers 2015). Approximately half of the Syrian refugees are under the age of 18 , and around 40 percent are under the age of 12 (Sirin and Rogers, 2015). More than one in five of over 870,000 refugees and migrants who have crossed the Mediterranean Sea to Europe is a child. Children are among the most at risk of the refugee migrants. For some children, the difficulties begin with perilous border crossings and rough seas. All are at risk of being exposed to sickness, injury, violence, exploitation and trafficking - violations of their rights and threats to their lives and well-being - while some tragically never arrive at their destination. (Global Migration Data Center 2015) 
According to the latest statistics reported by UNICEF (2019), by the end of 2018 an estimated 27,000 children were present in Greece. In Italy it was reported that 10,787 children were present in shelters for Unaccompanied and Separated Children (UASC), run by state authorities and non-profit entities, and Spain accounted for a total of 13,000 unaccompanied and separated children.

This literature review will examine, in four parts, the many difficulties child refugee face once they have arrived to Europe. The first part of the literature review will focus on welcoming the refugee and how it may cause conflict with the host countries' citizens and their domestic policies. The second part of the literature review will cover the conditions of the refugees' camps in different European countries. The third will cover the refugees' access to health care. The fourth will review the education that is offered to the refugees.

\section{Refugee's Welcome?}

When thousands of migrants left Budapest to march on a motorway towards Austria - and Germany - the German Chancellor, Angela Merkel, and her Austrian counterpart, Werner Faymann, took a far-reaching decision. Bypassing the ordinary rules of the EU's shared asylum system, both leaders agreed to permit asylum seekers entry into their countries. She appeared on talk shows to explain that Germany was under an obligation to help. Simultaneously, enthusiastic forms of civil society engagement in villages, towns and cities sprang up to provide assistance (Bock and McDonald 2019). On the ground, Germany's Willkommenskultur (welcoming culture) manifested through the considerable number of volunteers that reinforced early settlement and integration efforts. The Barometer of Public Opinion on Refugees conducted as part of the 2016 wave of the Socio-Economic Panel of the German Institute for Economic Research (Deutscher Intistut für Witschaftsforschung, DIW) indicated that an approximate $10 \%$ of the German population, amounting to over 8 million people, had helped refugees on site by accompanying them to appointments with the government or volunteering for language instruction (Stoyanova 2017).

The welcome of the Austrian Chancellor was not long lived as the Austrian government quickly turned their attention on to protect Austria's borders and were debating on building a fence or a wall. These heated debates amongst Austrian government parties led to the resignation of Werner Faymann as Austria Chancellor on May 9, 2016. (Rheindorf and Wodak 2017) Countries such as Greece were dealing with their own domestic and economic issues, immediately felt the pressure of the migration waves which became so great that the situation in Greece was described by the UNHCR (2017) as resembling a humanitarian crisis. In Greece refugees are often viewed in negative and hostile terms (Giannopoulos and Gill 2018). They are seen to represent a burden on the host country, and a particular source of discontent arises when refugees are perceived to have a better life than some of the Greeks themselves. According to Ellinas (2013) the economic crisis has brought a massive realignment of the Greek electorate away from mainstream parties, giving rise to antisystem and anti-immigrant sentiments.

The Asylum Information Database (AIDA 2019) on Greece, reported that in September of 2018, two unaccompanied children living in a shelter in Oreokastro, Thessaloniki were attacked by a group of ten people and in March 2019, in Samos, the parents' association has kept their children out of a primary school in order to protest against the participation of refugee children in classes. The immigrants also fear the local authorities as (Keith and LeVoy 2015) the policies which task police with enforcing migration regulations mean that undocumented migrants, including children, are unable to report violence to the police safely. They are unable to seek protection and redress without risk of detention and deportation, and regularly face immigration enforcement - or the threat of immigration enforcement - rather than protection and appropriate steps towards prosecution. This makes them 'zero risk' victims, and breeds a culture of impunity for violence. Greece is not the only country that has unwelcomed the refugee's as the Prime Minister of Hungary Viktor Orban, built a wall against refugees and triggered a collapse on the Balkans' borders. Prime Minister Miro Cerar of Slovenia said that his country will only accept Christian refugees and that Europe is going to drown. Norbert Hofer, the far-right leader in Austria that promised he will protect Austrian borders against the refugees. They all have a palpable enemy: the refugee (Postelnicescu 2016).

\section{Camp Conditions}

According to the UNHCR (2018) reporting on the conditions of the Reception Identification Center (RIC) in Samos, despite having capacity for 650 people, the centre and its surrounding area are currently hosting around 4,000 people - six times its design. By any measure, things are in crisis. Food and water supply is reportedly insufficient, sanitation is poor and security highly problematic. Many of the asylum-seekers arrive in Greece in a vulnerable state, but even those who turn up at the RIC in good condition soon find themselves suffering from health problems (AIDA 2019), The low number of staff under the Ministry of Health, particularly doctors and cultural staff mediators, are not sufficient to help refugees with medical and psychological needs. (UNHCR 2019)

In contrast to the overcrowding conditions for refugees in Greece, the Asylum Information Database (AIDA 2019) on Germany 
reports that most initial reception centres have a policy to accommodate single women and families in separate buildings or separate wings of their buildings, but in situations of overcrowding this policy could not be put into practice in many facilities in recent years. The AnKER centre in Manching/Ingolstadt for example provides separate rooms for vulnerable persons. The AnkER centre of Bamberg in Bavaria has a capacity of 3,400 places, for example, although it has never accommodated more than 1,500 persons at one time. It also reported that the facilities are often isolated or in remote locations. In general, two or more menus are on offer for lunch and the management of the catering facilities tries to ensure that specific food is provided with regard to religious sentiments. Because different policies are pursued on regional and local level, it is impossible to make general statements on the standards of living in the follow-up accommodation facilities.

The AIDA (2019) also reported on the conditions in Hungary where all refugees are placed in detention camps such as Nyirbatov. The detainees said the facilities were infested with bedbugs, and Human Rights Watch researchers observed rashes and bites on detainees. Staff said that eradicating the problem would be too costly. Though the temperature was cold, around 5 degrees, many people were without sweaters and were wrapped in bedsheets. Staff said detainees are expected to buy their own clothes. There are no programmes organised for teenage unaccompanied children, who often complain of boredom. Their pens and pencils are also taken away because of security risk.

\section{Health Care}

According to the United Nations Office of the High Commissioner on Human Rights, the Convention on the Rights of the Child (OHCHR 1989) States Parties recognize the right of the child to the enjoyment of the highest attainable standard of health and to facilities for the treatment of illness and rehabilitation of health. States Parties shall strive to ensure that no child is deprived of his or her right of access to such health care services. European countries such as France, Italy, Spain, Portugal and Norway stand out because they have explicit policies that aim to provide care on equal terms to the host population for all categories of migrant children. In contrast, Germany and Slovakia stand out as the European countries with the most restrictive policies. Twelve European countries have limited entitlements to health care for asylum seeking children, including Germany that stands out as the country with the most restrictive health care policy for children.(Ostergaard et al., 2017) Accessing medical care in Germany can be a gamble as Keith and LeVoy (2015) state that according to one law, undocumented migrants should have the same access to health services as asylum seekers - in cases of acute illness and pain, and maternity care there is another law that requires social welfare offices to report undocumented migrants to the immigration authorities in all but emergency care situations. These contradictory laws mean that undocumented migrants, including children, are only able to access emergency treatment free of charge from public health facilities and would be at risk of denunciation and deportation if they were to try to access any other health services. Therefore, in effect, the legal framework only entitles undocumented migrants to emergency care, and there are at times difficulties in accessing even this care. In France, the European Migration Network (2014) reports that, as soon as the Unaccompanied Minor (UAM) enters the shelter phase, the young person benefits from Universal Health Cover (Couverture Maladie Universelle) (CMU). After this, the young person under the care of the Social Child and Youth care services (ASE) has access to health care under common law. A health check is systematically carried out on admission to the ASE services. UAMs who do not come under the protection of the ASE, can benefit from State Medical Aid (AME), as irregularly staying foreign nationals. This access to State Medical Aid is not conditioned on the presence of three months on the French territory for minors, unlike for irregularly staying adults (European Migration Network 2014).

\section{Education}

Sirin, Rogers (2015) writes that during the 2014-2015 school year, 51 percent of all Syrian children did not attend school, and in the hardest -hit areas up to 74 percent of children were not enrolled. As of 2014 Syria's net primary education enrollment rate was the second -lowest in the world. Many children arrive in refugee camps are already at an educational disadvantage. Most of the time refugee children are behind in all subjects and will need to catch up while simultaneously learning a new language and adjust to an entirely new cultural and social environment. The acquisition of a second language is particularly challenging for children who have fallen behind in academic skills due to interruptions in their schooling. Additionally, the emotional trauma experienced by many refugee children may affect their cognitive, emotional, and social development. The EU member states have been facing challenges in providing decent opportunities in education for newly arrived refugees and integrating them into mainstream education. These challenges have intensified since 2015 with the arrival of larger numbers of refugees and asylum seekers (Thomas et al. 2018). Administrative procedures and legal restrictions represent barriers for migrants' inclusion into education when access to schooling is dependent on their legal status or the stage in the asylum process (Koehler et al. 2018). The education across Europe is different by reception centers as countries such as Austria, Belgium, Germany, Italy and Sweden amongst others, offer limited education classes such as language while they are in reception centers. The UK, Spain, Slovakia, Bulgaria and Greece 
do not have reception classes and are directly enrolled in mainstream education classes (Koehler et al. 2018). Some municipalities in Germany, such as Hamburg, have installed 'learning groups' in reception centres (classes of up to 15 children and adolescents, roughly divided into age groups, who receive German language lessons and partly alphabetization in Latin writing). In principle, attendance at the learning groups is obligatory for all young people under age 18, but absenteeism is high (Thomas et al. 2018). In some cases, children receive language education for a few hours a day in the asylum seeker centres, rather than going to a regular school and have regular school hours. In Greece, education is compulsory for all children irrespective of their legal status; the non-enrolment of minors is penalised, and sanctions can be imposed on parents and guardians who do not register their children or neglect school attendance. However, this is rarely applied to vulnerable groups such as refugee parents (Crul et al. 2019).

According to the AIDA (2019) report on Access to Education in Greece, children aged between 6-15 years, living in dispersed urban settings (such as UNHCR accommodation, squats, apartments, hotels, and reception centres for asylum seekers and unaccompanied children), may go to schools near their place of residence, to enroll in the morning classes alongside Greek children, at schools that will be identified by the Ministry.

In both Sweden and Germany there is no obligation to attend school for those still in the process of status definition, who therefore do not yet have a residence permit (Bourgonje, 2010; Rydin et al., 2012, as cited in Crul 2019), although in theory, German language courses are obligatory in Germany in the reception centres. In some cases, children receive language education for a few hours a day in the asylum seeker centres, rather than going to a regular school and have regular school hours. For the refugees in Italy, the Italian legislation provides that all children until the age of 16 , both nationals and foreigners, have the right and the obligation to take part in the national education system. Under the Reception Decree, unaccompanied asylum-seeking children and children of asylum seekers exercise these rights and are also admitted to the courses of Italian language. The Reception Decree makes reference to Article 38 TUI, which states that foreign children present on Italian territory are subject to compulsory education, emphasizing that all provisions concerning the right to education and the access to education services apply to foreign children as well (AIDA Italy 2019).

\section{Conclusions}

The European Union as a whole has in many ways failed the refugees but also the European member countries that were struggling prior to the drastic mass migration at the start of the Middle East turmoil. Europe has always had to deal with legal and illegal migration from those same countries in the Middle East and as far as Asia. It is hard to place blame on a country as Greece with their abysmal record of camp conditions and their access to health care when they have their own domestic and economic issues to deal with. Greece being the first point of entry into Europe through many of their islands in the Mediterranean was in no position to take on such a disaster even only as if it was a transit point for the refugees. Countries as Germany were able to manage and avoid being overwhelmed due to their strong economy. The European Union was built to take on a collective role as a whole but has shown their inability to organize and be prepared for disasters such as the refugee crisis and has failed miserably. With all its power, the European Union and its 28 members were unable to coordinate and provide in some cases the basics needs for the refugees. In doing so, it seems that they allowed each country to fend for themselves which gave a voice to the nationalist movements that led to the violence that the children and all other migrants face. Countries like Hungary and Austria amongst others, closed their borders and were in discussions of building fences and walls on their borders. If we are to call it the European "Union", why should some of the member countries have no issues providing at least the basics of hum a dignity, such as the right to health care and housing, while others are denied health care and are locked up in detention centers with overflowing sanitation problems which lead to more health issues. The European Union should not have conflicting policies, rather it should be a collective and organized effort by all of its members that are in "union" with its goals. One of its unquestionable and undeniable goals was for the EU and its member states is to protect the lives of the more than 200,000 unaccompanied and minor child refugees with their borders.

\section{References}

1. AIDA 2019 Mapping Asylum Procedures, Reception Conditions, Detention and Content of Protection in Europe." Asylum Information Database |Conditions in Reception Facilities: Germany. https://www.asylumineurope.org/reports/country/germany/ reception-conditions/housing/conDitions-receptionfacilities (November 2, 2019).

2. AIDA 2019. "Access to Education." Access to education - Greece | Asylum Information Database. https://www.asylumineurope.org/reports/country/greece/re ception-conditions/employment-and-education/accesseducation (November 2, 2019).

3. AIDA 2019. "Conditions in Reception Facilities." Conditions in reception facilities - Greece | Asylum Information

Database. 
https://www.asylumineurope.org/reports/country/greece/re ception-conditions/housing/conditions-receptionfacilities\#footnote51_oj4okh8 (November 2, 2019).

4. AIDA 2019. "Conditions in Detention Facilities." Conditions in detention facilities - Hungary | Asylum Information Database.

https://www.asylumineurope.org/reports/country/hungary/ detention-asylum-seekers/detention-conditions/conditionsdetention\#footnote4 99iuf6a (November 2, 2019).

5. AIDA 2019. "Italy." Country Report - Italy | Asylum Information

Database.

http://www.asylumineurope.org/reports/country/italy

(November 2, 2019).

6. Bock, Jan-Jonathan, and Sharon Mcdonald. 2019. Refugees Welcome? Difference and Diversity in a Changing Germany. p2 New York: Berghahn Books

7. Chak, Farhan Mujahid. 2017. "Am I Not a Child? The Neglect of Child Refugees in Europe.” TRT World.

https://www.trtworld.com/worldcitizen/images/PDFs/amin otachild.pdf (November 2, 2019).

8. Crul, Maurice et al. 2019. "How the Different Policies and School Systems Affect the Inclusion of Syrian Refugee Children in Sweden, Germany, Greece, Lebanon and Turkey." Comparative Migration Studies. https://comparativemigrationstudies.springeropen.com/arti cles/10.1186/s40878-018-0110-6 (November 2, 2019).

9. Edwards, Adrian. "Global Forced Displacement Hits Record High.” UNHCR.(2016) https://www.unhcr.org/enus/news/latest/2016/6/5763b65a4/global-forced-

displacement-hits-record-high.htm (November 2, 2019).

10. Ellinas, Antonis A. 2013. "The Rise of Golden Dawn: The New Face of the Far Right in Greece." South European Society and Politics 18(4): 543-65. doi: 10.1080/13608746.2013.782838.

11. European Migration Network. Policies, Practices and Data on Unaccompanied Minors in 2014. 2014. 3rd ed. Paris:https://ec.europa.eu/home-

affairs/sites/homeaffairs/files/what-we-

do/networks/european_migration_network/reports/docs/em n-studies/unaccompanied-

minors/10a france uams study english version final.pdf 12. Giannopoulou, Chrisa, and Nick Gill. 2018. "Asylum Procedures in Greece: The Case of Unaccompanied Asylum Seeking Minors.” Asylum Determination in Europe: 10930. doi: 10.1007/978-3-319-94749-5_6.

13. IOM and UNICEF Data Brief. "Migration of Children to $\quad 2015$. https://www.iom.int/sites/default/files/press release/file/IO M-UNICEF-Data-Brief-Refugee-and-Migrant-Crisis-inEurope-30.11.15.pdf (November 2, 2019).
14. Keith, Liliana, and Michele LeVoy. 2015. "Protecting Undocumented Children: Promising Policies and Practices from Governments.” PICUM. http://picum.org/Documents/Publi/2015/Protecting_undoc umented_children-

Promising_policies_and_practices_from_governments.pdf (November 2, 2019).

15. Koehler, Claudia, Heckmann Friedrich, Daniel Goeler, and Michiel Lippens. 2018. "Multi-Country Partnership to Enhance the Education of Refugee and Asylum-Seeking Youth in Europe.” Sirius - Policy Network on Migrant Education. https://www.researchgate.net/publication/326113676_SIRI US-Policy_Network on_Migrant_Education_MultiCountry Partnership To Enhance The Education_Of Re fugee_And_Asylum-Seeking_Youth_In_Europe-

Perae_Comparative_Report. (November 2, 2019)

16. OHCR. 1989. "Convention on the Rights of the Child."

https://www.ohchr.org/en/professionalinterest/pages/crc.as px (November 2, 2019).

17. Ostergaard, Liv Stubbe et al. 2017. "Restricted Health Care Entitlements for Child Migrants in Europe and Australia." European Journal of Public Health 27(5): 86973. https://doi.org/10.1093/eurpub/ckx083 (November 2, 2019).

18. Postelnicescu, Claudia. 2016. "Europe's New Identity: The Refugee Crisis and the Rise of Nationalism." Europe's Journal of Psychology 12(2): 203-9. doi: 10.5964/ejop.v12i2.1191.

19. Rheindorf, Markus, and Ruth Wodak. 2017. "Borders, Fences, and Limits-Protecting Austria from Refugees: Metadiscursive Negotiation of Meaning in the Current Refugee Crisis.” Journal of Immigrant \& Refugee Studies 16(1-2): 15-38. doi: 10.1080/15562948.2017.1302032.

20. Sirin, Selcuk R., and Lauren Rogers-Sirin. 2017. "The Educational and Mental Health Needs of Syrian Refugee Children."

https://www.migrationpolicy.org/research/educationaland-mental-health-needs-syrian-refugee-children

(November 2, 2019).

21. Stoyanova, Anastasia. 2017. "Refugees Not Welcome: Investigating Reasons for Violence Against Refugees in Germany.” Academia.edu. https://www.academia.edu/37528121/Refugees_Not_Welc ome_Investigating_Reasons_for_Violence_Against_Refug ees in Germany (November 2, 2019).

22. UNHCR 2019." Greece". UNHCR: The UN Refugee Agency Fact Sheet.

https://bit.ly/2E717It. (November 2, 2019). 
23. UNHCR 2016 "Global Trends Forced Displacement In 2015.” The UN Refugee Agency. https://www.unhcr.org/576408cd7.pdf (November 2, 2019).

24. UNHCR 2018. "UNHCR Urges Greece to Accelerate Emergency Measures to Address Conditions on Samos and Lesvos." https://www.unher.org/enus/news/briefing/2018/11/5be15c454/unhcr-urges-greeceaccelerate-emergency-measures-address-conditionssamos.html (November 2, 2019).

25. UNHCR. 2017. "Situation on Greek Islands Still Grim despite Speeded Transfers." Refworld. http://www.refworld.org/docid/5a3cec6b4.html.

(November 2, 2019).

26. UNICEF. 2019. "Latest Statistics and Graphics on Refugee and Migrant Children." UNICEF. https://www.unicef.org/eca/emergencies/latest-statisticsand-graphics-refugee-and-migrant-children (November 2, 2019). 